\title{
Real_time Continuous Assessment Method for Mental and Physiological Condition using Heart Rate Variability
}

\author{
Yutaka Yoshida Member (Aichi Institute of Technology) \\ Kiyoko Yokoyam Member (Nagoya City University) \\ Naohiro Ishii Non-member (Aichi Institute of Technology)
}

Keywords : heart rate variability, real-time assessment

It is necessary to monitor the daily health condition for preventing stress syndrome. In this study, we proposed the method assessing the mental and physiological condition, such as the work stress or the relaxation, using heart rate variability at real time and continuously.

Heart rate variability index using our proposed method are heart rate (HR), and the ratio of the number of extreme points (NEP). We decided calculation window width to 20 beats. This method was calculated these indexes using queue processing in one beat interval. Moreover, we adopted as a base the average heart rate variability index for 180 seconds under resting condition, when considering normalization to eliminate individual differences in mental and physiological condition assessment. Then, we derived the rate of the heart rate variability index which is calculated from each beat for that average level. These indexes show HRratio and NEPratio. Fig1 shows HRratio time series and NEPratio time series.

To evaluate proposed method, we assessed three conditions such as sitting rest, performing mental arithmetic and watching relaxation movie using our proposed algorithm. The participants of our experiments were 26 healthy male university students ( $22 \pm 2 \mathrm{yr})$.

We assessed stress or relaxation with the use of a moving average of HRratio time series and NEPratio time series. The threshold values to assess mental and physiological condition shows equation (1), equation (2), and equation (3). However, w is calculation window width $(1 \sim 20$ beats $)$ of moving average. Assessment process, first, assess stress or non-stress using equation (1), next, assess relaxation or rest using equation (2) and equation (3) for non-stress.

We calculated the suitable calculation window width of moving average and correct rate of assessment. In the Results, the suitable calculation window width of moving average was considered approximately 7 beats. The assessment correct rate was $71.9 \%$ and $55.8 \%$, when performing mental arithmetic and watching relaxation movie respectively in window width 7 beats.

In this method, the mental or physiological condition was assessed using only 20 regressive heart beats, so this method is considered as the real time assessment method.

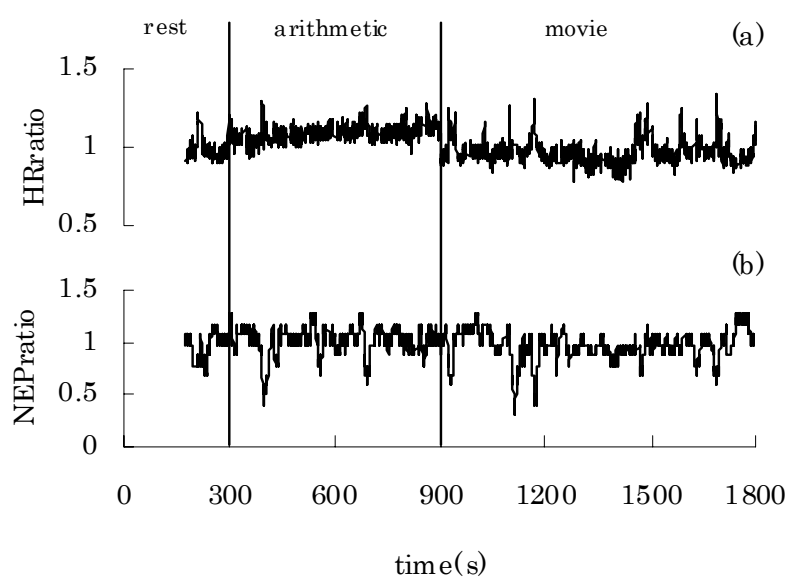

(a) HRratio, (b) NEPratio

Fig. 1. An example of time course of assessment index

$\frac{1}{w} \sum_{n=0}^{w-1} \operatorname{HRratio}(i+n)>1.016 \ldots$

$\left.\begin{array}{c}\frac{1}{w} \sum_{n=0}^{w-1} \operatorname{HRratio}(i+n) \leqq 1.016 \\ \text { and } \\ \frac{1}{w} \sum_{n=0}^{w-1} \operatorname{NEPratio}(i+n)>0.972\end{array}\right\}$

$$
\left.\begin{array}{c}
\frac{1}{w} \sum_{n=0}^{w-1} \operatorname{HRratio}(i+n) \leqq 1.016 \\
\text { and } \\
\frac{1}{w} \sum_{n=0}^{w-1} \operatorname{NEPratio}(i+n) \leqq 0.972
\end{array}\right\}
$$




\title{
心拍変動時系列を用いた生体状態の実時間連続判定手法
}

\author{
学生員 吉田 豊* 正 員 横山 清子** \\ 非会員 石井 直宏*
}

\section{Real-time Continuous Assessment Method for Mental and Physiological Condition using Heart Rate Variability} Yutaka Yoshida*, Member, Kiyoko Yokoyama**, Member, Naohiro Ishii*, Non-member

It is necessary to monitor the daily health condition for preventing stress syndrome. In this study, it was proposed the method assessing the mental and physiological condition, such as the work stress or the relaxation, using heart rate variability at real time and continuously.

The instantanuous heart rate (HR), and the ratio of the number of extreme points (NEP) and the number of heart beats were calculated for assessing mental and physiological condition. In this method, 20 beats heart rate were used to calculate these indexes. These were calculated in one beat interval.

Three conditions, which are sitting rest, performing mental arithmetic and watching relaxation movie, were assessed using our proposed algorithm. The assessment accuracies were $71.9 \%$ and $55.8 \%$, when performing mental arithmetic and watching relaxation movie respectively.

In this method, the mental and physiological condition was assessed using only 20 regressive heart beats, so this method is considered as the real time assessment method.

キーワード : 心拍変動性, 実時間判定

Keywords : heart rate variability, real-time assessment

\section{1. はじめに}

ストレス社会といわれる現在，我々は日常生活の中で 様々なストレスを受けている。ストレスはヒトに精神的な 障害を与えるだけでなく, 自律神経活動などにも悪影響を あたえ, ストレス性下痢や自律神経失調症などの疾病を引 き起こし, さらに症状が悪化すると過労死などを引き起こ す危険性もある(1)。

そのため，これらのストレスを緩和，もしくは解消する ために, リラクゼーションを目的とした多くの音楽や映像 の提供，様々なリラクゼーション手法が商業ベースで行わ れている。また, 労働環境改善を目的として労働作業中に バックグラウンドミュージックを流寸ことなども行われ， その効果に関する研究も報告されている(2)。このようなリラ

* 愛知工業大学大学院 経営情報科学研究科

T470-0392 愛知県豊田市八草町八千草 1247

Graduate School Business Administration and Computer Science, Aichi Institute of Technology

1247, Yakusa-cho-yachigusa, Toyota-shi, Aichi 470-0392

** 名古屋市立大学大学院 芸術工学研究科

干 464-00831 名古屋市千種区北千種 2-1-10

School of Design and Architecture, Nagoya City University 2-1-10, Kitachikusa, Chikusa-ku, Nagoya-shi, Aichi 464-00831
クゼーション手法の効果の確認や, 日常的な健康管理のた めに，自身のストレス・リラクゼーション度合を認識する ことは重要である。

労働や作業に伴う生体負担度の推定は心拍, 血圧, ホル モン, 酸素代謝量などの生理指標, 心理評価, 作業成績な ど様々な面から行われる。特に, 心拍変動時系列は運動や 精神作業時の生体負担度, 作業中の緊張感や作業への集中, 眠気, 自律神経活動等, 様々な生体の状態を反映する(3)。一 方, リラックス度合の評価には, 脳波の $\alpha$ 波を用いる場合 が多い。しかし，脳波は信号強度が小さく，作業中など日 常活動中の正確な測定は必ずしも容易ではない。

心拍変動時系列は，作業を妨げることなく容易に連続測 定を行うことができ, ホルタ心電計による日常生活中の長 時間無拘束測定が可能となっている。そのため, 日常的に 簡便にストレス・リラックス度合を推定するためには, 無 拘束・連続測定に適した心拍変動時系列を用いることが望 ましい。

そこで，本研究では心拍変動時系列から簡便に算出され る心拍変動指標を用いて, 精神作業やリラクゼーション映 像視聴時などの生体状態を実時間連続判定する装置開発を 目指す。心拍変動指標の代表的なものである Heart Rate 
$(\mathrm{HR})$, 変動係数 $(\mathrm{CVRR})$, 時系列の極值の個数の割合 (NEP) を実時間連続算出するアルゴリズムを提案する。ま た，個人差を考慮せずに判定する機能の検討，および，提 案アルゴリズムを用いて暗算による精神ストレス時とリラ クゼーション映像視聴時の生体状態判定を試み, 提案手法 を評価した。

\section{2. 心拍変動指標}

心拍変動時系列からリアルタイムに生体状態を判定する ために用いた心拍変動指標について説明する。

〈2·1〉 心拍変動時系列 心拍変動時系列として, 心 電図の隣接する $\mathrm{R}$ 波 (心臓の収縮に対応して現れる波の頂 点）と $\mathrm{R}$ 波との時間間隔，すなわち，拍動間隔時系列を利 用する。図 1 に心拍変動時系列の一例を示す。横軸は拍数, 縦軸は拍動間隔である。

〈2·2〉均心拍数(HR : Heart Rate) HR は, 1 分間を 拍動間隔時系列の平均值で除したものである。単位は beats/min(bpm)である。ここでは， 1 拍の $\mathrm{R}-\mathrm{R}$ 間隔で 1 分間を除した瞬時心拍数を $\mathrm{HR}$ として用いた。

\section{$\langle 2 \cdot 3\rangle$ 変動係数（CVRR:Coefficient of Variance）}

CVRR は(1)式で示されるように, 心拍変動時系列の標準 偏差 $S D_{R R}$ をその平均值 $A V_{R R}$ で除したものである。拍動間 隔時系列の変動のばらつきを平均值に依存せずに表すこと ができる指標である。若年健常者の安静時では 10～13\%の 值となり，緊張など生体に負担がかかると值が小さくな る(4)。

$$
C V R R=\frac{S D_{R R}}{A V_{R R}} \times 100(\%)
$$

〈2·4〉 NEP(Number of Extreme Point) NEP は, 拍 動間隔時系列の極值の個数と解析対象データ数との比率と して，(2)式のように定義する。ここで， $R(i)$ は $i$ 拍目の 拍動間隔, $n$ は全データ数, $Y_{i}$ は $R(i)$ が極值を示す点で あるかどうかを判定する変数である。

$$
N E P=\frac{1}{(n-2)} \sum_{i=2}^{n-1} Y_{i}
$$
ただし，

$$
\begin{array}{ll}
Y_{i}=1 & \{R(i)-R(i-1)\} \cdot\{R(i+1)-R(i)\}<0 \\
Y_{i}=0 & \{R(i)-R(i-1)\} \cdot\{R(i+1)-R(i)\} \geqq 0
\end{array}
$$

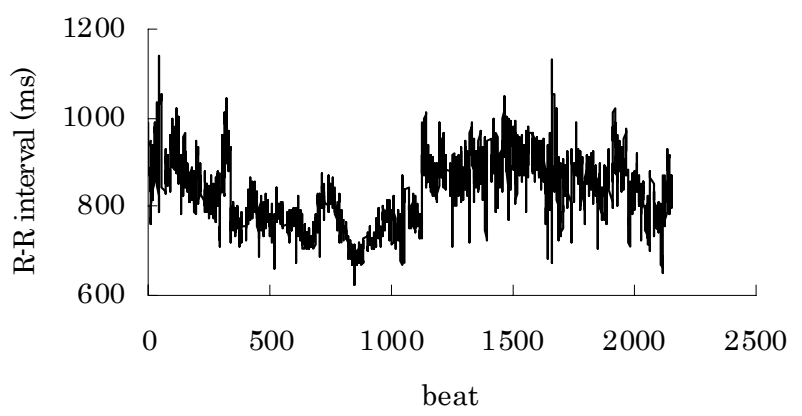

図 1 拍動間隔時系列の一例

Fig. 1. An example of $R-R$ interval time series.
NEP は, 拍動間隔時系列の変動周波数と平均心拍数の両 方に関連する(5)。例えば, 安静仰臥位では拍動間隔時系列の 変動周波数は呼吸回数に比例する。従って, 同じ平均心拍 数であれば, 呼吸回数が速くなるほどNEPが有意に増加し, 仰臥位から立位変換による交感神経優位時ではNEPが減少 すると報告されている(5)。

\section{3. 心拍変動指標の算出アルゴリズム}

心拍変動指標を実時間連続算出するための窓幅の決定と アルゴリズムの作成を行った。さらに, 心拍変動指標の值は 個人によって異なるため, 生体状態判定の閾值を個人によ らず一定に設定できるように，規格化の検討を行った。

CVRR，NEP いずれも瞬時の拍動間隔から算出すること は困難で, ある時閒空内の複数データから算出される。少 ないデータ数で算出すれば, 実時間性は高まるが, 算出值 の安定性は減少する。一方, 拍動間隔時系列には, 主な周 波数成分として, 約 4 秒周期の呼吸性変動(6) と約 10 秒周期 の血圧調節系変動があるとされている(7)。空内で算出するパ ラメータが空の位置の相違に依存しないためには, 空幅が 変動周期の整数倍となることが望ましい。前述の変動の主 要周期の 10 秒と 4 秒は，心拍数 $60 \mathrm{bpm}$ を想定すれば, 10 拍と 4 拍となる。空幅は 10 拍と 4 拍との最小公倍数となる 20 拍とした。

19 拍目までは $\mathrm{n}$ 個のデータ $(\mathrm{n} \leqq 19)$ で算出する。ただし, CVRR は標準偏差を求めなければならないため, 2 拍目から 算出し, NEP は 3 点で極值を決定するため 3 拍目から算出 した。19 拍目以降は 20 拍のデータで算出し, 一番古いデ ータを一つ出して新しいデータを一つ入れるキュー型処理 を用いて 1 拍ごとに心拍変動指標を算出した。HR は, 新し く入力される拍動間隔から瞬時心拍数として計算した。

生体状態判定の個人差を除去するための規格化は, 安静 時 180 秒間の心拍変動指標の平均值を基準とし, その基準 值に対する 1 拍ごとに算出される心拍変動指標の值の比率 を求めることとした。従って, 提案アルゴリズムは安静 180

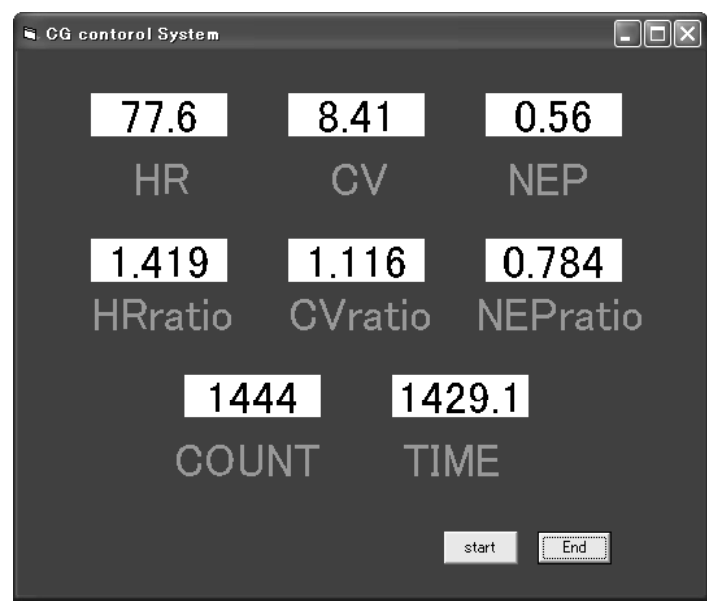

図 2 心拍変動指標の表示画面

Fig. 2. Calculated index of heart rate variability. 
秒後から生体状態を判定することになる。

図 2 に算出值の表示例を示す。ここで, HRratio, CVratio, NEPratio はそれぞれ, 規格化した HR, CVRR, NEP であ る。COUNT は測定開始時からの拍数の累積, TIME は拍 動間隔時系列の累積から算出した測定開始からの経過時間 が毎拍提示される。

\section{4. 実験方法}

提案したアルゴリズムを用いて，暗算による精神ストレ ス時とリラクゼーション映像視聴時の生体状態を判定する ための実験方法を説明する。

被験者は若年健常者 26 名 $(20 \pm 2$ 歳, $\operatorname{mean} \pm \mathrm{SD})$ で, 実験 直前にカフェイン，煙草等の刺激物の摂取および食事をひ かえた。本実験は名古屋市立大学で行い, 実験を行った部 屋は空のない防音室で空調装置により温度を $20^{\circ} \mathrm{C}$ で一定と した。すべての被験者に本研究の主旨および目的に関する 説明を行い, 了承を得た。

心電図 $\mathrm{R}-\mathrm{R}$ 間隔(拍動間隔)の測定方法は，携帯型心電計 LRR－03（GMS）で三点胸部誘導法により連続測定した。

表 1 に実験プロトコールを示す。まず，椅座位安静で 5 分間測定を行い，次に精神負荷作業を行った。精神負荷作 業には，パソコンによる暗算作業を用いた。作業内容は， パソコン画面に提示される 2 桁 $\times 1$ 桁の掛算を暗算で解き, 答えをキーボードから入力する。答えが正解の場合, その まま次の問題が提示され, 不正解の場合は, コンピュータ による警告音と不正解のメッセージが表示されたのち, 次 の問題が提示される。これを 10 分間行う。暗算作業に用い たパソコンは， A4 型液晶ディスプレイを使用した。

暗算作業終了後, リラクゼーション映像を 15 分間観賞す る。映像観賞用のテレビには平面の 21 型テレビを用いた。 観賞用の映像には DVD ソフト「NATURE〜 relaxation japan〜 (日本の心風景)」を使用した。

実験終了後，実験に関しての主観評価を行った。内容は, (1)安静時にリラックスできたか, (2)暗算時に集中できたか, (3)映像視聴時にリラックスできたか，の 3 項目である。評 価は 1〜 5 の 5 段階評価で，評価 1 は「全くできない」，評 価 5 は「非常にできた」とした。

統計解析は， 5 分間の安静時間のうち, 終了前の 2 分間 を stage 1 とした。10 分間の暗算時間のうち, 前半の 5 分間 を stage 2 , 後半の 5 分間を stage 3,15 分間の映像視聴時間 のうち, 最初の 5 分間を stage4, 次の 5 分間を stage 5 , 最 後の 5 分間を stage6 に分割して行った。

表 1 実験プロトコール

Table 1. The protocorl of experiment.

\begin{tabular}{c|c|c|c|c|c|c|c}
\hline stat & \multicolumn{2}{|c|}{ rest } & \multicolumn{2}{|c|}{ arithmetic } & \multicolumn{4}{c}{ movie } \\
\hline stage & & 1 & 2 & 3 & 4 & 5 & 6 \\
\hline time(min) & 3 & 2 & 5 & 5 & 5 & 5 & 5 \\
\hline
\end{tabular}

\section{5. 結果・考察}

〈5·1〉 生体状態変化における指標の変化 図 3(a), (b)，（c）はそれぞれ同一被験者の HRratio，CVratio， NEPratio の時間に対する変化の一例である。横軸は時間で ある。測定開始からの 180 秒閒は比率を求めるために必要 な平均值を算出したため, 180 秒経過後からを表示してい る。心拍変動指標を実時間連続的に算出できることが確認 できる。

図 4(a), (b), (c)は HRratio, CVratio, NEPratio の各 stage における平均值を被験者毎に求め, その分布を箱ひげ図で 表現したものである。中央の線分はメディアン值, 箱の上 端は分布の $75 \%$ タイル值, 下端は $25 \%$ タイル值を表す。箱 から伸びる線分の上端は最大値, 下端は最小值を表す。stage 変化に対して一元配置分散分析を行った結果, HRratio $(\mathrm{p}<0.01)$, CVratio $(\mathrm{p}=0.047)$, NEPratio $(\mathrm{p}=0.030)$ と なり, いずれもステージ変化に対して有意に変動している 結果となった。

(a)

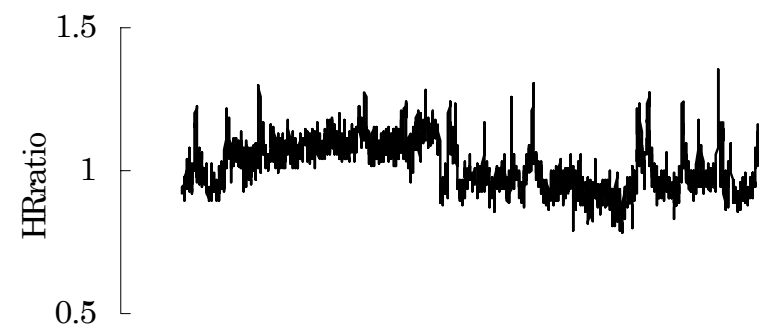

(b)

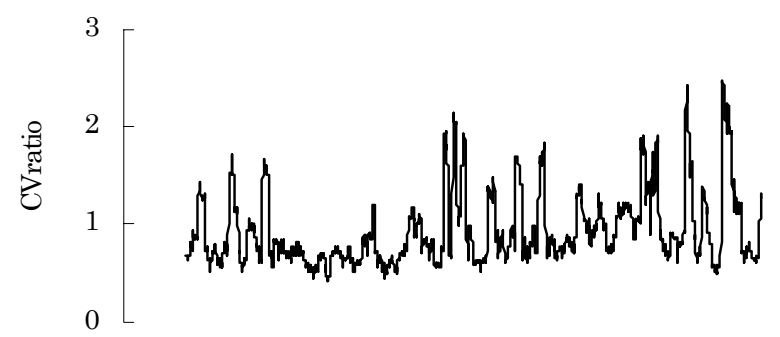

(c)

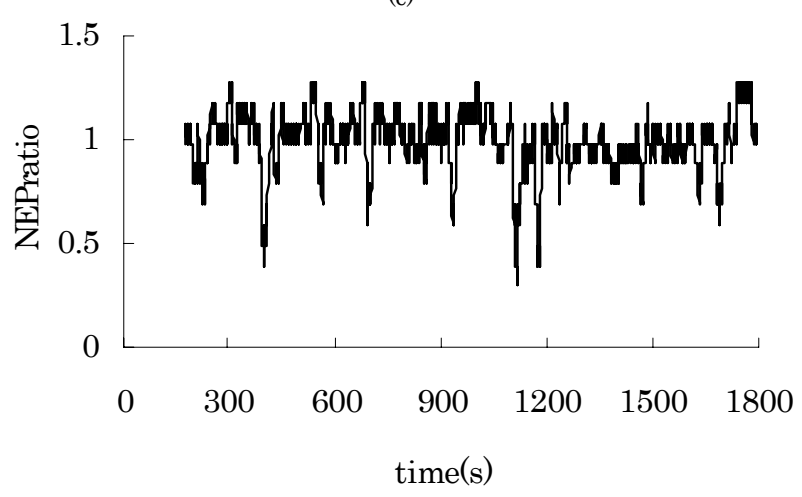

(a) HRratio, (b) CVratio, (c) NEPratio

図 3 判定指標の時間変化の一例

Fig. 3. An example of time course of assessment index. 
(a)

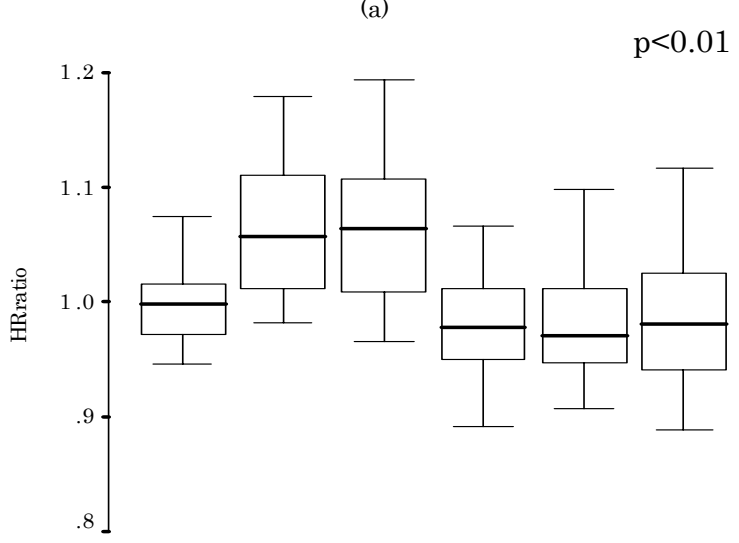

(b)

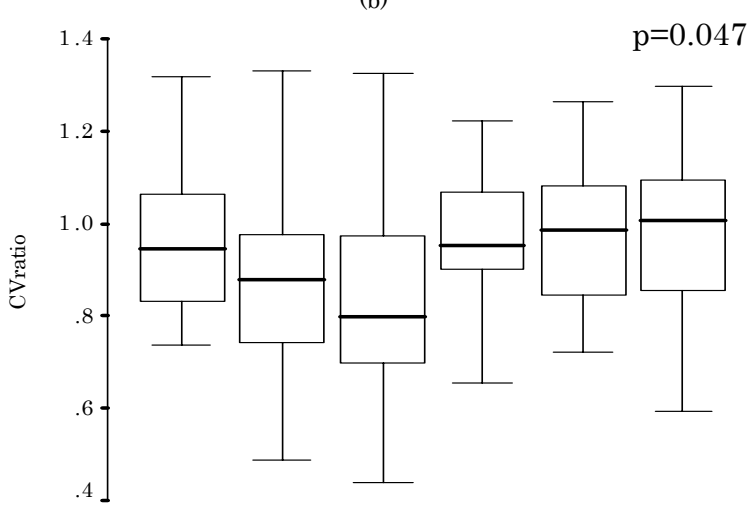

(c)

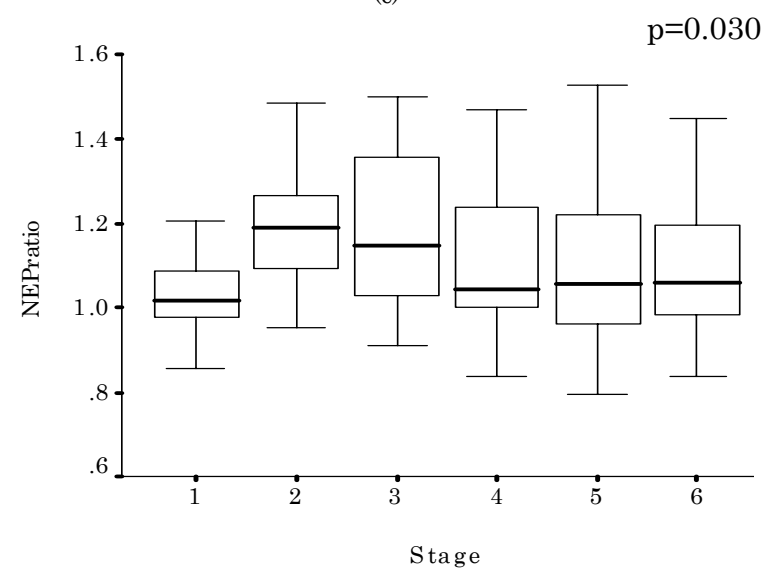

(a) HRratio, (b) CVratio, (c) NEPratio

図 4 判定指標の stage の平均值

Fig. 4. Mean value of stage of assessment index.

また, 主観評価の平均值と標準偏差は, 項目 (1) $3.75 \pm 0.74$, 項目 (2) $3.66 \pm 0.85$ ，項目 (3) $4.02 \pm 0.94$ となり，いずれも平 均值が 3 (どちらともいえない)を超えており, 安静時, 映像 視聴時はリラックスできており，暗算時は集中できている 結果となった。また, 安静と映像視聴では, リラクゼーシ ヨンに対する評価值が映像の方が高い結果となっている。 従って, HRratio, CVratio, NEPratio は暗算による精神 ストレス状態, リラクゼーション映像視聴によるリラック ス状態, 安静状態を区別することができると考えられる。

$\langle 5 \cdot 2\rangle$ 生体状態の判定精度 暗算時とリラクゼーシ ヨン映像視聴時の生体状態を判定するため, 被験者 26 人分
の心拍変動指標の值を基礎データとして, 閾值の決定を行 った。算出した心拍変動指標は, それぞれの生体状態に対 して有意な変化が認められたため, 閯值を決める際, 指標 を組み合わせることにより閾值の精度向上を図った。そこ で, p 值が小さい HRratio と NEPratio を組み合わせて生 体状態を判定することにした。

生体状態の判定方法は, まず, HRratio によって, 暗算 による精神ストレス状態か, それ以外の安静状態もしくは 映像視聴によるリラクゼーション状態の非精神ストレス状 態かを判定する。次に非精神ストレス状態に対して, NEPratio によって, 安静状態か映像視聴によるリラクゼー ション状態かを判定する。閯值については, HRratio は stage1の 75\%タイル值（1.016）を用いた。NEPratio の閾 值は stage5, stage6 の 25\%タイル值（0.972）の平均值を 用いた。この閾值に対して, HRratio 時系列と NEPratio 時系列の各々の移動平均值で生体状態を判定した。なお, 移動平均值の算出空は 1 拍ずつシフトした。

これらの閾值の妥当性の確認と判定による最適な移動平 均の空幅を決定するための評価指標として, HRratio 時系 列と NEPratio 時系列から(3)式, (4)式, (5)式に示す生体 状態判定の正答率を算出した。

$$
\text { seitou } A=\left(\frac{1}{(N-w+1)} \sum_{i=1}^{N-w+1} A_{i}\right) \times 100(\%)
$$

ただし，

$$
\begin{aligned}
& \begin{cases}A_{i}=1 & \frac{1}{w} \sum_{n=0}^{w-1} \text { HRratio }(i+n)>1.016 \\
A_{i}=0 & \text { 上記以外 }\end{cases} \\
& \text { seitouB }=\left(\frac{1}{(N-w+1)} \sum_{i=1}^{N-w+1} B_{i}\right) \times 100(\%)
\end{aligned}
$$

ただし，

$$
\begin{aligned}
& \left\{\begin{array}{l}
B_{i}=1 \\
\left\{\begin{array}{l}
\frac{1}{w} \sum_{n=0}^{w-1} \text { HRratio }(i+n) \leqq 1.016 \\
\frac{1}{w} \sum_{n=0}^{w-1} \text { NEPratio }(i+n)>0.972
\end{array}\right. \\
B_{i}=0 \quad \text { 上記以外 }
\end{array}\right. \\
& \text { seitouC }=\left(\frac{1}{(N-w+1)} \sum_{i=1}^{N-w+1} C_{i}\right) \times 100(\%)
\end{aligned}
$$

ただし，

$$
\left\{\begin{array}{l}
C_{i}=1 \\
C_{i}=0 \quad \text { 上記以外 }
\end{array}\right.
$$

ここで，（3)式の seitouA，（4)式の seitouB，（5)式の 

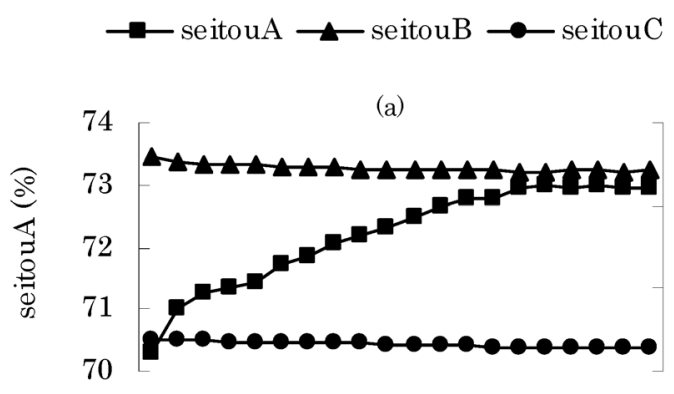

30

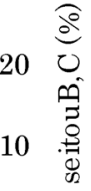

0

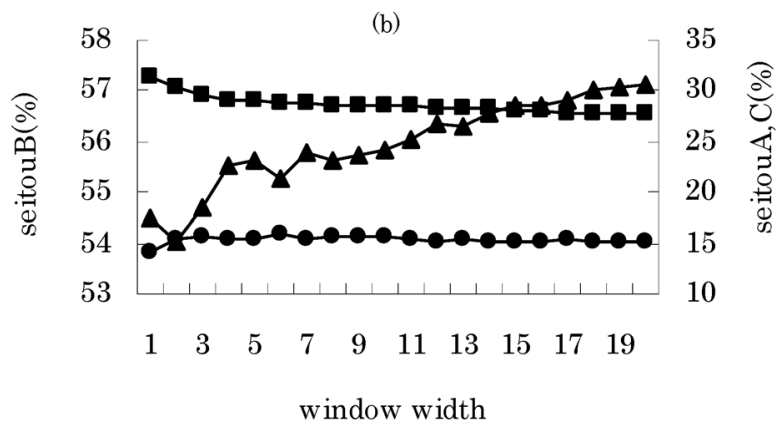

(a) mental arithmetic, (b) watching relaxation movie

図 5 空幅に対する生体状態判定の正答率

Fig. 5. Relationship between correct rate of mental and physiological condition assessment and the window width.

seitouC，はそれぞれ，暗算による精神ストレス状態判定， 映像視聴によるリラクゼーション状態判定, 安静状態判定 の正答率である。 $\mathrm{N}$ は HRratio 時系列と NEPratio 時系列 のデータ数, $\mathrm{w}$ は移動平均值の算出空幅, $A_{i}, B_{i}, C_{i}$ は生 体状態を満たしているかどうかを判定するための変数で, 満たしていれば 1 ，いなければ 0 である。

図 5(a),(b)はそれぞれ全被験者の暗算時と映像視聴時の空 幅の変化に対する生体状態判定の正答率の平均值である。 空幅に関しては, 空幅が広くなると正答率が高くなるが, 生体状態判定の時間遅れが大きくなるため, 空幅は狭い方 が望ましい。従って, 正答率の増加速度が低下し始めてい る空幅 7 拍程度が適切であると思われる。

図 6 は, 空幅 7 拍における全被験者の状態判定正答率の 平均值と標準誤差である。すなわち, 図 5 の窓幅 7 拍にお ける状態判定正答率である。暗算作業時を対象として状態 判定を行った図 6 （a)では，71.9\%の精度で精神ストレスと 判定した。また, 残りの $24.8 \%$ はリラックス状態判定とな り，3.3\%は安静と判定される結果となった。

一方, リラクゼーション映像視聴時を対象として状態判 定を行った図 6(b)では, 55.8\%の精度でリラックス状態と判 定した。残りの $15.4 \%$ は安静判定, $28.8 \%$ は精神ストレス判 定となった。

主観評価により, リラクゼーション映像視聴時と安静時 ともに評価值が平均以上あるため, 主観的なリラックス感 があると考えられる。リラクゼーション映像視聴時におい ては, リラックス状態の判定正答率が $55.8 \%, 15.4 \%$ は安静 (a)

(b)

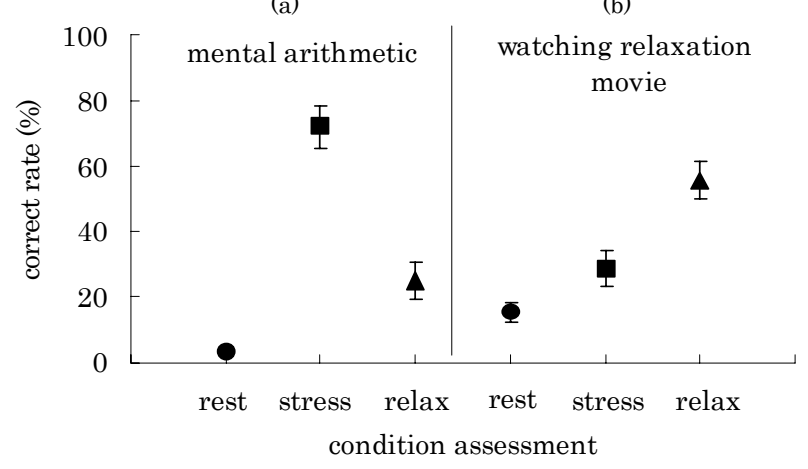

(a) mental arithmetic, (b) watching relaxation movie

図 6 空幅 7 拍における正答率の平均値と標準誤差

Fig. 6. Average and standard error of correct rate in window width 7 beats.

時のリラックス状態と判定となったため, すなわち, リラ クゼーション映像視聴時では, $71.2 \%$ の精度で主観的なリラ ックス状態を判定可能であると考えられる。

今回の実験では, 若年者を対象として行ったが, 心拍変 動の様相が異なる高齢者等については, 閾值や空幅の決定 法について検討が必要である。

現状の暗算作業時や音楽刺激の心拍変動時系列解析の研 究では, 数分間の心拍変動時系列からパワースペクトルを 算出して, 統計的に自律神経バランスを評価する手法が行 われているが(8)(9), それに対して, 20 拍程度の心拍で心拍 変動指標を算出し, 状態判定結果を毎拍ごとに実時間連続 出力してモニタリングする装置の開発研究例は認められ ず，幅広い応用の可能性が期待できる。

\section{6. まとめ}

本研究では, 心拍変動時系列から簡便に算出される心拍 変動指標を用いて, 日常生活中に利用できる生体状態の実 時間連続判定方法の提案を行った。

提案アルゴリズムは個人差を考慮することなく判定指標 を 1 拍ごとに連続算出可能である。また, 生体状態判定に 必要な閾值を暗算時とリラクゼーション映像視聴時から決 定し, 連続的な生体状態判定手法の精度を評価した結果, 暗算作業時では約 $72 \%$ の精度で精神ストレスと判定した。 リラクゼーション映像視聴時では $55.8 \%$ の精度でリラック ス状態と判定され，15.4\%は安静と判定された。さらに, 生 体状態判定に必要な空幅も 7 拍程度で判定可能であるため, 即時性の高い方法である。

今回の閾值は, 被験者 26 人分の心拍変動指標の值から決 定したが, 精度向上のために個人の様々な状態の心拍変動 指標の值を基礎データとして閾值を決定することを考えて いる。

\section{謝 辞}

本研究を行うにあたり, 財団法人堀情報科学振興財団に 助成を頂戴いたしました。深く感謝の意を表します。

(平成 18 年 3 月 14 日受付, 平成 18 年 9 月 4 日再受付) 


\section{文献}

（1）早野順一郎：「心拍変動によるストレス反応の分析」，ストレス科学, 10, 1, pp.76-80 (1995)

(2) E. Landenberger-Leo : "Effect of music on the general feeling of persons performing monotonous work", Med.Pr., Vol.37, No.2, pp.347-352 (1986)

（3）日本生理人類学会計測部会編：「人間科学計測ハンドブック」, pp.387-399 (1996)

(4) K. Kazuhiro, H. Ogata, S. Miyake, and M. Kamiyo : "Correlation between the coefficient of variance of ECG R $-\mathrm{R}$ interval (CVRR) and autonomic nervous system", The Autonomic Nervous System,Vol.28, No.2, pp.95-101 (1991) (in Japanese)

井上和宏・緒方 甫 $-三$ 宅晋司・神代雅春 : 「心電図 $\mathrm{R}-\mathrm{R}$ 間隔変動 係数 $\left(\mathrm{CV}_{\mathrm{R}-\mathrm{R}}\right.$ 值 $)$ における自律神経の関与」, 自律神経, 28,2 , pp.95-101 (1991)

(5) Y. Yoshida, K. Yokoyama, and N. Ishii : "A New Measure for Evaluating Cardiac Autonomic Function using Extreme Points of $\mathrm{R}-\mathrm{R}$ Interval Time Series", The 5th International Workshop on Biosignal Interpretation, pp.143-145 (2005)

(6) Task force of the European Society of Cardiology and the NorthAmerican Society of Pacing and Electrophysiology : Heart rate variability, standards of measurement, physiological interpretation, and clinical use", Circulation, Vol.93, No.5, pp.1043-1065 (1996)

（7）日本自律神経学会編：「自律神経機能検査第 2 版」, 文光堂, pp.40-47 (1995)

(8) N. Ohisa, M. Suzuki, H. Sasaki, T. Yanbe, K. Yoshida, H. Harigae, and M. Kaku : "Heart rate variability in autonomic function and brain tissue oxygenation while performing mathematical calculations", The Autonomic Nervous System, Vol.40, No.2, pp.166-169 (2003) (in Japanese)

大久典子・鈴木真悠子 - 佐々木春香 - 家山智之 ·吉田克己 ・ 張替秀 郎, 賀来満夫 : 「計算負荷における心拍変動と脳神経細胞の酸素代 謝」，自律神経, 40,2, pp.166-169 (2003)

(9) N. Ohisa, K. Yoshida, T. Yanbe, and M. Kaku : "Effect of autonomic nervous system activity while listening to music", The Autonomic Nervous System, Vol.42, No.3, pp.265-269 (2005) (in Japanese)

大久典子・吉田克己・家山智之・賀来満夫 : 「音楽刺激が自律神経に 及ぼす影響」，自律神経, 42, 3, pp.265-269 (2005)

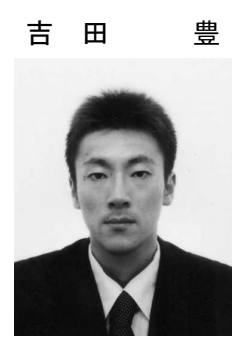

（学生員） 1977 年 5 月 19 日生。 2002 年 3 月 大同工業大学大学院工学研究科修了。2004 年 7 月名古屋市立大学大学院研究員。2005 年 4 月 愛知工業大学大学院経営情報科学研究科博士 後期課程入学。現在に至る。2005 年自律神経 学会論文賞受賞。生体情報工学, 人間工学の研 究に従事。自律神経学会, 生体医工学会会員。

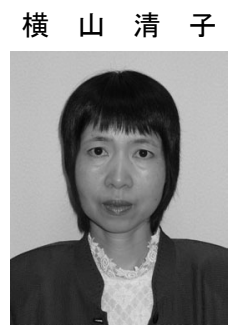

（正員） 1959 年 12 月 2 日生。 1984 年 3 月名 古屋工業大学大学院情報工学専攻修士課程修 了。1984 年 4 月豊田工業高等専門学校電気工 学科助手。1996 年 4 月名古屋市立大学芸術工 学部助教授。現在に至る。生体信号処理, 人間 工学の研究に従事。工学博士。2005 年自律神 経学会論文賞受賞。電子情報通信学会, 情報処理学会, 生体医工学会, 人間工学会会員。

石井直宏 (非会員) 1940 年 3 月 23 日生。 1963 年 3 月

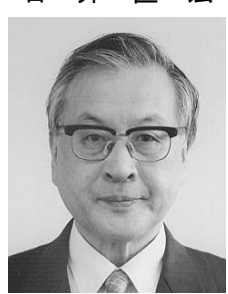
東北大学工学部電気工学科卒業。1968 年同大 学院博士課程電気及び通信工学専攻修了。同 4 月同大学助手。1 1975 年 4 月名古屋工業大学情 報工学科助教授。1982 年同教授。1989 年同大 学知能情報システム学科教授。2003 年 4 月愛 知工業大学情報通信工学科教授。現在, 同大学, 経営情報科学部情報科学科コンピュータシス テム専攻教授。今まで生体工学, 人工知能, 情報工学に関する研究 に従事。 